\title{
Zebra mussel (Dreissena polymorpha) selective filtration promoted toxic Microcystis blooms in Saginaw Bay (Lake Huron) and Lake Erie
}

\author{
Henry A. Vanderploeg, James R. Liebig, Wayne W. Carmichael, Megan A. Agy, \\ Thomas H. Johengen, Gary L. Fahnenstiel, and Thomas F. Nalepa
}

\begin{abstract}
Microcystis aeruginosa, a planktonic colonial cyanobacterium, was not abundant in the 2-year period before zebra mussel (Dreissena polymorpha) establishment in Saginaw Bay (Lake Huron) but became abundant in three of five summers subsequent of mussel establishment. Using novel methods, we determined clearance, capture, and assimilation rates for zebra mussels feeding on natural and laboratory $M$. aeruginosa strains offered alone or in combination with other algae. Results were consistent with the hypothesis that zebra mussels promoted blooms of toxic M. aeruginosa in Saginaw Bay, western Lake Erie, and other lakes through selective rejection in pseudofeces. Mussels exhibited high feeding rates similar to those seen for a highly desirable food alga (Cryptomonas) with both large $(>53 \mu \mathrm{m})$ and small $(<53 \mu \mathrm{m})$ colonies of a nontoxic and a toxic laboratory strain of $M$. aeruginosa known to cause blockage of feeding in zooplankton. In experiments with naturally occurring toxic M. aeruginosa from Saginaw Bay and Lake Erie and a toxic isolate from Lake Erie, mussels exhibited lowered or normal filtering rates with rejection of $M$. aeruginosa in pseudofeces. Selective rejection depended on "unpalatable" toxic strains of $M$. aeruginosa occurring as large colonies that could be rejected efficiently while small desirable algae were ingested.
\end{abstract}

Résumé : Mycrocystis aeruginosa, une cyanobactérie qui forme des colonies planctoniques, s'est multipliée dans la Baie de Saginaw (Lac Huron) durant trois des cinq étés qui ont suivi l'établissement de la Moule zébrée (Dreissena polymorpha), alors qu'elle n'était pas abondante durant les deux années qui ont précédé cet établissement. Des méthodes inédites ont permis de déterminer les taux de clearance, de capture et d'assimilation de Moules zébrées alimentées de souches naturelles et de souches de laboratoire de $M$. aeruginosa, présentées seules ou en combinaison avec d'autres algues. Nos résultats s'accordent avec l'hypothèse qui veut que les Moules zébrées favorisent, par des rejets sélectifs dans leurs pseudofèces, la formation de fleurs d'eau à $M$. aeruginosa de souche toxique dans la baie de Saginaw, dans la région occidentale du lac Érié et dans d'autres lacs. Nourries de grandes $(>53 \mu \mathrm{m})$ et de petites $(<53 \mu \mathrm{m})$ colonies d'une souche non-toxique et d'une souche toxique de laboratoire de M. aeruginosa, qui inhibent l'alimentation chez le zooplancton, les moules maintiennent des taux élevés d'alimentation, semblables à ceux que l'on observe lorsqu'on les nourrit d'une algue très recherchée (Cryptomonas). Dans des expériences d'alimentation utilisant des souches naturelles de $M$. aeruginosa toxiques de la baie de Saginaw et du lac Érié et un isolat toxique du lac Érié, les moules présentent des taux de filtration réduits ou normaux et rejettent $M$. aeruginosa dans leurs pseudofèces. Ce rejet sélectif dépend de la présence de grandes colonies de souches toxiques «à goût désagréable» de $M$. aeruginosa qui peuvent être éliminées facilement, alors que les petites algues appétissantes sont ingérées.

[Traduit par la Rédaction]

\section{Introduction}

Noxious blooms of colonial cyanobacteria such as Microcystis, Anabaena, and Aphanizomenon are well known symptoms of eutrophication caused by excessive phosphorus loading (Smith 1983; Sommer et al. 1986). These blooms, which were common on Saginaw Bay (Stoermer and Theriot 1985; Bierman et al. 1984) and Lake Erie (Makarewicz 1993) during the 1960s and 1970s, diminished as phosphorus controls were instituted during the mid-1970s.

Microcystis and other cyanobacterial blooms may have serious consequences to aquatic ecosystem function and

Received August 30, 2000. Accepted March 1, 2001. Published on the NRC Research Press Web site on May 11, 2001. $\mathrm{J} 15950$

H.A. Vanderploeg, ${ }^{1}$ J.R. Liebig, and T.F. Nalepa. Great Lakes Environmental Research Laboratory, National Oceanic and Atmospheric Administration, 2205 Commonwealth Blvd., Ann Arbor, MI 48105-2945, U.S.A.

W.W. Carmichael. Department of Biological Sciences, Wright State University, 3640 Colonel Glenn Hwy., Dayton, OH 45435, U.S.A.

M.A. Agy and T.H. Johengen. University of Michigan Cooperative Institute for Limnology and Ecosystems Research, 2205 Commonwealth Blvd., Ann Arbor, MI 48105-2945, U.S.A.

G.L. Fahnenstiel. National Oceanic and Atmospheric Administration/Great Lakes Environmental Research Laboratory, Lake Michigan Field Station, 1431 Beach Street, Muskegon, MI 49441-1098, U.S.A.

${ }^{1}$ Corresponding author (e-mail: vanderploeg@glerl.noaa.gov). 
health, to aesthetics, and to wildlife and human health. Microcystis and some other cyanobacteria produce a potent class of hepatotoxins called microcystins that can poison aquatic organisms as well as wildlife, domestic animals, and humans that drink or ingest algae in the water (Carmichael 1996). The major exposure pathway of microcystin is through ingestion, although some toxins can be released upon death of the cells (Lampert 1982; Nizan et al. 1986; Fulton and Paerl 1987). The toxicity and large colonial size of Microcystis and other nuisance cyanobacteria can lower ingestion and assimilation rates of zooplankton (Lampert 1982; Nizan et al. 1986). Toxicity, lowered assimilation rates, and low nutritional quality of Microcystis can cause decreased survival and reproduction of zooplankton, thus leading to inefficient pelagic food webs (Fulton and Paerl 1987; Vanderploeg et al. 1996).

After zebra mussels (Dreissena polymorpha) became established in Saginaw Bay, there were anecdotal reports of Microcystis aeruginosa blooms on Saginaw Bay. Microcystis blooms were not expected on the bay because of decreased phosphorus loading. Thus, we wondered if zebra mussels were somehow causing these blooms. This hypothesis seemed plausible, as Microcystis blooms were reported in other systems where zebra mussels became established. In September 1995, there was an intense bloom of $M$. aeruginosa that was visible from shore and satellite imagery as a surface scum that covered much of the western basin of Lake Erie (Budd et al. 2001). Cyanobacterial blooms had not been seen on Lake Erie since phosphorus loading reductions were instituted (Makarewicz 1993; Nicholls and Hopkins 1993). Microcystis blooms following zebra mussel invasions have also been reported for Gull Lake and Gun Lake in Michigan (S. Hamilton, Michigan State University, East Lansing, Mich., personal communication) and the Bay of Quinte (Lake Ontario) (K. Nicholls, Ontario Ministry of the Environment, Toronto, Ont., personal communication). Additionally, late-summer blooms of the colonial cyanobacterium Aphanizomenon in Oneida Lake followed the zebra mussel invasion (Horgan and Mills 1997). An exception to this pattern occurred in the Hudson River, where Microcystis and other cyanobacteria have virtually disappeared since the establishment of zebra mussels (Smith et al. 1998).

The potential connection between zebra mussels and $M$. aeruginosa has important water quality management implications; it appears that zebra mussels have reversed progress made by nutrient control programs by increasing the probability of a cyanobacterial bloom. For example, in Saginaw Bay (Bierman et al. 1984), Lake Erie (Makarewicz 1993), Gull Lake (Tessier and Lauff 1992), and the Bay of Quinte (K. Nicholls, Ontario Ministry of the Environment, Toronto, Ont., personal communication), blooms occurred after drastic reductions in phosphorus loading and improvements in water quality.

Our preliminary observations involving traditional bottle experiments and direct observations with video during September 1994 showed that mussels did not ingest $M$. aeruginosa but nearly continually filtered and produced pseudofeces. This behavior led us to hypothesize that zebra mussels promoted and maintained $M$. aeruginosa blooms via rejection of Microcystis as pseudofeces. Fully stated, the hy- pothesis argued that $(i)$ mussels would continually filter in the presence of Microcystis, (ii) mussels would ingest all algae except Microcystis, and (iii) mussels would produce loosely consolidated pseudofeces that would be injected back into the water column. If zebra mussel biomass and weight-specific filtering rate of the mussels allowed the mussels to clear the water at a rate representing a significant proportion of algal growth rate, then selective filtering would lead to M. aeruginosa dominance.

To investigate the selective feeding hypothesis, we initiated a series of experiments of $D$. polymorpha feeding on naturally occurring $M$. aeruginosa from Saginaw Bay and Lake Erie and on pure laboratory cultures of $M$. aeruginosa, including a strain isolated from the Lake Erie bloom of September 1995 (Brittain et al. 2000). In this paper, we examine how $M$. aeruginosa colony size, toxicity, and strain type affect mussel feeding behavior. Combining these experimental results with biomass of zebra mussels in Saginaw Bay and Lake Erie allowed us to quantify the magnitude of the selection process. Also, because $M$. aeruginosa blooms on Saginaw Bay were not documented, we examined time histories of phytoplankton composition before and after the zebra mussel invasion.

\section{Materials and methods}

\section{Study sites and collections}

Dreissena polymorpha and water from Saginaw Bay were collected from Station 5, a 3.5-m-deep station with a cobble, sand, and gravel substrate, in the inner bay (Nalepa et al. 1995) as part of a 6-year study of the impact of zebra mussels on the ecology of the bay. Temperature, chlorophyll $a(\mathrm{Chl} a)$, particulate organic carbon (POC), and algal composition were taken at this station at $1 \mathrm{~m}$ depth during May, September, and October in 1990 and at least monthly during 1991-1996. Dreissena polymorpha and water from western Lake Erie were collected during the M. aeruginosa bloom of September 1995 in Hatchery Bay of South Bass Island $\left(40^{\circ} 40^{\prime} 01^{\prime \prime} \mathrm{N}, 82^{\circ} 49^{\prime} 61^{\prime \prime} \mathrm{W}\right)$. Generally, both inner Saginaw Bay (Nalepa et al. 1996) and western Lake Erie (Schertzer et al. 1987) are isothermal and well mixed. Western Lake Erie has a mean depth of $7.1 \mathrm{~m}$, and inner Saginaw Bay has a mean depth of $5.1 \mathrm{~m}$.

Dreissena polymorpha were hand collected by divers using SCUBA. Rocks with attached clusters of D. polymorpha were wrapped in moist paper towels and placed in coolers for transport. Mussels and water were kept cool and transported on the day of collection to the Great Lakes Environmental Research Laboratory (GLERL) and then kept at ambient temperature and photoperiod.

\section{Reacclimation of mussels to natural seston containing Microcystis}

A reacclimation period was provided to allow mussels to reestablish natural feeding behaviors for the ambient lake seston. Typically, mussels were collected in the late morning and used in experiments after $\sim 17 \mathrm{~h}$ of reacclimation to lake seston at the ambient lake temperature. Upon arrival at GLERL within 4-5 h of collection, mussels typically ranging in length between 13 and $16 \mathrm{~mm}$ were gently removed from the rocks to which they were attached by cutting their byssal threads with a razorblade, and periphyton adhering to the shells was gently brushed off. Twenty to 30 of these mussels were placed in a $30-\mathrm{L}$ aquarium filled with lake water collected that day. After $\sim 14 \mathrm{~h}$, all mussels were placed in another $30-\mathrm{L}$ aquarium filled with new lake water for $3 \mathrm{~h}$ before being used in the feeding experiments. 
Chlorophyll, temperature, POC, and ash-free dry weight

For the time histories of temperature and triplicate measurements of Chl $a$ and POC, methods of Nalepa et al. (1996) were used. For Chl $a$ determinations for feeding experiments, the sequential filtration apparatus (Bowers 1980) fitted with a GF/F filter downstream of a $53-\mu m-m e s h$ Nitex filter (cut from Nitex screen) was used to collect $>53$ and $<53 \mu \mathrm{m}$ size fractions. These filters were extracted in $N, N$-dimethylformamide and analyzed fluorometrically (Speziale et al. 1984). Precision $(\mathrm{SE} / \bar{X})$ for all replicate Chl $a$ analyses for monitoring and experiments was better than 5\%.

Ash-free dry weights (AFDW) of mussels were determined by removing mussels from shells, drying for 2 days at $60^{\circ} \mathrm{C}$, and ashing at $550^{\circ} \mathrm{C}$ for $1 \mathrm{~h}$. In some experiments, AFDW was determined from length-AFDW regressions of mussels collected at the same station and time.

\section{Algal culturing and phytoplankton analysis}

Algae were harvested in exponential phase, except for M. aeruginosa strain CCAP 1450/11(described below), which was harvested in the early stationary phase of growth. The appropriate quantity of algal suspension was diluted into ambient seston or 0.2$\mu \mathrm{m}$-filtered lake water as required for the experiment. All culture media were filter sterilized with a $0.2-\mu \mathrm{m}$ membrane filter. Cryptophytes were grown in WC media (Vanderploeg et al. 1996) modified by doubling $\mathrm{NaHCO}_{3}$, halving $\mathrm{NaNO}_{3}$, and adding $0.1 \mathrm{mM} \mathrm{NH} \mathrm{Nl}_{4} \mathrm{Cl}$ a light intensity of $40 \mu \mathrm{mol}$ quanta $\cdot \mathrm{m}^{-2} \cdot \mathrm{s}^{-1}$ on $16 \mathrm{~h}$ light : $8 \mathrm{~h}$ dark cycle at $20^{\circ} \mathrm{C}$. All M. aeruginosa strains were cultured in BG-11 $1_{0}+\mathrm{NaNO}_{3}(2 \mathrm{mM})+\mathrm{NaHCO}_{3}(10 \mathrm{mM})$ medium (Rippka and Herdman 1992) plus the WC vitamin mixture under continuous light at $40 \mu \mathrm{mol}$ quanta $\cdot \mathrm{m}^{-2} \cdot \mathrm{s}^{-1}$ at $25^{\circ} \mathrm{C}$.

Lake water samples for phytoplankton enumeration were preserved in $1 \%$ Lugol's solution, and 2- to $50-\mathrm{mL}$ subsamples (depending on algal concentration) were filtered onto membrane filters for permanent mounting on slides; cell dimensions of the different taxa were converted to cell carbon for reporting biomass (Fahnenstiel et al. 1998). Some experimenters working with laboratory cultures reported algal concentrations in units of cells per litre. For comparison with our laboratory results, we converted them into volumetric units of cubic millimetres per litre from reported cell dimensions.

\section{Toxin concentration}

Microcystin, the toxin produced by Microcystis, was measured by enzyme-linked immunosorbent assay (ELISA) of polyclonal antibodies to microcystin-LR (An and Carmichael 1994). Seston or algal cultures were filtered onto GF/F filters and extracted in methanol. Typically, 1-2 L of seston and 25-50 mL of Microcystis culture were filtered, and triplicate ELISAs were run with a precision $(\mathrm{SE} / \bar{X})$ of $\sim 10 \%$. Microcystin concentration was normalized to Chl $a$ concentration and dry weight of the seston or Microcystis culture. To estimate microcystin concentration per unit of Microcystis $\mathrm{Chl} a$ in seston, we assumed that the proportion of Microcystis Chl $a$ in the seston was the same as that for algal carbon estimated from algal counts.

\section{General design of filtering experiments}

To obtain estimates of filtering rates and other feeding rate variables on natural seston and algal cultures, we developed a novel experimental approach based on methods of Walz (1978) and Vanderploeg et al. (1995). Experiments were usually conducted in 2-L beakers in dim light $\left(4-8 \mu \mathrm{mol}\right.$ quanta $\left.\cdot \mathrm{m}^{-2} \cdot \mathrm{s}^{-1}\right)$. Gentle bubbling provided agitation to assure mixing in four experimental (with mussels) and three control (without mussels) beakers and to keep particles suspended during the 1.5- to 3-h experiments. Usually, four mussels were placed in each experimental beaker. Enough phosphorus and nitrogen were added to the beakers to sat- urate nutrient uptake by the algae and to prevent different algal growth rates from occurring in the control versus experimental beakers as a result of mussel nutrient excretion; final concentrations were 12.5 and $250 \mu \mathrm{M}$ phosphate and nitrate, respectively, or $2.5,25$, and $25 \mu \mathrm{M}$ phosphate, nitrate, and ammonium.

We measured changes in Chl $a$ concentration in small $(<53 \mu \mathrm{m})$ and large $(>53 \mu \mathrm{m})$ size fractions to examine the mussels' response to naturally occurring $M$. aeruginosa, which occurred as colonies in the larger size fraction. Measuring Chl $a$ concentrations in the water column and on the entire beaker contents after resuspending all settled material at the end of the experiment allowed us to do a mass balance of mussel-induced changes to distinguish between what Chl $a$ was filtered and what was assimilated. Typically, two 200-mL samples were taken by wide-bore volumetric pipette from the water column and from the mixed beaker contents for Chl $a$ analyses.

Filtering (clearance) rate $(F)$ for particle removal in each experimental container was calculated by (Vanderploeg et al. 1995)

$$
F=(V / n t) \ln \left(C_{\mathrm{wc}} / Z_{\mathrm{wc}}\right)
$$

where $C_{\mathrm{wc}}$ is the mean $\mathrm{Chl} a$ concentration in the water column at the end of the experiment in control containers, $Z_{\mathrm{wc}}$ is the Chl $a$ concentration in the water column of an experimental container at the end of the experiment, $V$ is the volume of water in the container during the experiment, $n$ is the number of mussels, and $t$ is the duration of the experiment.

We calculated this filtering rate for both chlorophyll size fractions and used the filtering rate on the preferred size fraction $\left(F_{\text {pref }}\right)$, i.e., the size fraction having the highest filtering rate, to estimate pumping rate (Vanderploeg et al. 1995). The $F_{\text {pref }}$ would closely approximate pumping rate if particles in the preferred size fraction were efficiently filtered and if feces and pseudofeces production added back to the water column in this size category was low (Vanderploeg et al. 1995).

The product of pumping rate and "average" concentration of Chl $a$ in the water column $\left(\bar{C}_{\mathrm{wc}}\right)$ gave $\mathrm{Chl} a$ removed, i.e., the capture rate $(\mathrm{CR})$

$$
\mathrm{CR}=F_{\text {pref }} \bar{C}_{\mathrm{wc}}
$$

$\bar{C}_{\mathrm{wc}}$ was calculated with the formula given by Frost (1972):

$$
\bar{C}_{\mathrm{wc}}=\left(Z_{\mathrm{wc}}-C_{0}\right) /\left(\ln Z_{\mathrm{wc}}-\ln C_{0}\right)
$$

where $C_{0}$ is the mean initial concentration of chlorophyll in all containers.

To calculate assimilation rate and the corresponding clearance rate for assimilated material, we used the following approach. Using equations analogous to eqs. 1 and 3 , a filtering rate $\left(F_{\mathrm{T}}\right)$ for total Chl $a$ in the beakers (after mixing beaker) and "average" concentration of Chl $a\left(\bar{C}_{\mathrm{T}}\right)$ in each experimental beaker were calculated. Analogous to eq. 2, we calculated assimilation rate $(A)$ as

$$
A=F_{\mathrm{T}} \bar{C}_{\mathrm{T}} \text {. }
$$

Using $A$ given by eq. 4 and the basic definition of clearance rate (eq. 2), the filtering rate for Chl $a$ assimilated was calculated from the Chl $a$ available in the water column by

$$
F_{\mathrm{A}}=A / \bar{C}_{\mathrm{wc}} .
$$

All filtering rates were normalized to AFDW of the mussels used in the experiments as well as to gill surface area calculated from the gill area to mussel length relationship given by Lei et al. (1996). This latter normalization, which was used throughout this paper, was chosen to provide filtering estimates that were independent of mussel size (Kryger and Riisgård 1988; Lei et al. 1996) and condition (weight for a given length), which can change with 
site, reproductive status, and season (Nalepa et al. 1993; H.A. Vanderploeg, unpublished data).

To calculate $A$ or $\mathrm{CR}$ as a percentage of mussel body carbon, we converted $\mathrm{Chl} a$ feeding rate to carbon feeding rate by multiplying Chl $a$ feeding rate by the ratio of seston particulate carbon (POC) to $\mathrm{Chl} a$ concentration. AFDW of mussels was converted to carbon content by multiplying AFDW by 0.524 (Nalepa et al. 1993).

All feeding rate variables were calculated for each size fraction and for the total of both size fractions. The size fraction referred to was put in parentheses next to the variable, and when no reference to a size fraction is presented, it refers to the variable calculated from the sum of chlorophyll in both size fractions. Note that $A$, by definition, equals $A(<53)+A(>53)$, but $F_{\mathrm{A}}$ does not usually equal $F_{\mathrm{A}}(<53)+F_{\mathrm{A}}(>53)$. The relative $F_{\mathrm{A}}$ values of the two size fractions provide estimates of selectivities for the total filteringingestion-assimilation process for algae in the two size-classes (Vanderploeg 1994). Unless there is significant survival of algae during gut passage, relative $F_{\mathrm{A}}$ values closely approximate selectivities for ingestion. All feeding rate variables were tested to see if they were significantly different $(P<0.05)$ from zero using a two-tailed $t$ test.

\section{Design for experiments with Microcystis in natural seston}

The goal of the experiments with natural seston that contained $M$. aeruginosa was to determine feeding rate variables on natural $M$. aeruginosa colonies in contrast with other seston. Two experiments were conducted using unmodified seston: Saginaw Bay (SB) seston (11 July 1995) and Lake Erie (LE) seston (21 September 1995) (Table 1). Other experiments added Rhodomonas minuta or Cryptomonas ozolini, small $(5 \mu \mathrm{m}$ and $8 \mu \mathrm{m})$ highly digestible cryptophytes of high food quality (Vanderploeg et al. 1996), to unmodified seston or to $>53,53-153 \mu \mathrm{m}$, or $>153 \mu \mathrm{m}$ size fractions of seston dominated by $M$. aeruginosa (Table 1). Experiments involving cryptophyte addition were designed to show filtration and rejection abilities of the mussels when offered a small desirable alga in the presence of naturally occurring Microcystis.

In the experiment "SB seston > $53 \mu \mathrm{m}+$ Rhodomonas," we gently concentrated natural seston on a $53-\mu \mathrm{m}$ screen and added it and Rhodomonas to $0.2-\mu \mathrm{m}$-filtered lake water to produce the chlorophyll size distribution in Table 1 . In the experiment "LE seston + Rhodomonas," Rhodomonas was added to LE seston to enrich the $<53 \mu \mathrm{m}$ size fraction final concentration of $\sim 4 \mu \mathrm{g} \mathrm{Chl} a \cdot \mathrm{L}^{-1}$. Both of these enrichment experiments were performed 1 day following experiments with the natural seston, and mussels were kept in natural seston before they were added, without acclimation, to the cryptophyte-amended suspensions.

The experiments performed with SB seston + Cryptomonas on 15 August 1997 were sequentially performed with the same mussels previously acclimated to natural seston for $\sim 1$ day (Table 1). The first experiment used seston concentrated on a $153-\mu \mathrm{m}$ screen added to $0.2-\mu \mathrm{m}$-filtered lake water enriched with Cryptomonas. In the second experiment, we added seston in the size range 53$153 \mu \mathrm{m}$ by collecting seston on a $53-\mu \mathrm{m}$ screen that had first been filtered through a $153-\mu \mathrm{m}$ screen to see if mussels would better ingest "smaller" than "larger" Microcystis colonies (Table 1). The mussels were acclimated for $1 \mathrm{~h}$ with the experimental mixture of seston and Cryptomonas prior to each experiment.

\section{Design of experiments with laboratory cultures of Microcystis}

Experiments with three different laboratory strains of $M$. aeruginosa were performed to evaluate effect of strain, microcystin concentration, and colony size on mussel feeding and behavior. We selected strains having different microcystin concentration (Table 2) that maintained some degree of colony formation in cul- ture to allow examination of mussel feeding on large versus small colonies or individual cells. CCAP 1450/11 contained no microcystin (Table 2). We chose PCC 7820 because it is known to be toxic and severely depress feeding and survival in Daphnia magna (Nizan et al. 1986). LE-3, the most toxic strain in this study (Table 2), was isolated from the M. aeruginosa bloom on Lake Erie in September 1995 (Brittain et al. 2000). The work with the LE-3 strain and other strains was particularly important for examining feeding on Microcystis colonies in the $<53 \mu \mathrm{m}$ fraction because colonies in this size category were not available in natural seston.

Acclimation to these experimental mixtures of laboratory cultures was similar to the reacclimation procedure described for natural seston; however, acclimation periods varied according to experiment (Table 2). Dreissena polymorpha used in these experiments were maintained in the laboratory on Algae Diet C (preserved Thalassiosira, Skelatonema, Isochrysis, and Chaetoceros) (Coast Seafoods Co., South Bend, Wash.) supplemented with C. ozolini in large well-mixed and aerated aquaria (Vanderploeg et al. 1996).

Experiments 1 and 2 looked at feeding rate variables for a single strain of $M$. aeruginosa (Table 2). Experiment 1 with CCAP $1450 / 11$, in addition to examining the effect of a particular strain type, examined the response of mussels to a high concentration of Microcystis, as found during a bloom (Table 2). Experiment 2, as well as Experiments 3 and 4, used much lower algal concentrations as might occur before a bloom to determine selectivity processes leading to bloom formation.

The multitreatment Experiments 3 and 4 each used the same set of mussels with three different algal treatments (Table 2). Experiment 3 evaluated the mussel response to different-sized colonies of the LE-3 strain of M. aeruginosa. Treatment 3A explored the mussels' response to the LE-3 strain presented as small colonies ( $<53 \mu \mathrm{m}$ size fraction) produced by screening the suspension through a $53-\mu \mathrm{m}$ screen. Treatment $3 \mathrm{~B}$ examined the effects of a more even distribution of colony sizes. Treatment 3C with Cryptomonas was a control to show the effects of a highly desirable alga.

Experiment 4 examined the response of mussels to mixture of small colonies of the LE-3 strain of M. aeruginosa and Cryptomonas. Treatment 4A with Cryptomonas was used to establish a baseline of effects of high-quality food alone. Experiment 4B was done to establish what the effects of small colonies (mean cells per colony $=4.3$ ) of $M$. aeruginosa strain LE-3 offered alone. These colonies were prepared by pouring the culture through a $37-\mu \mathrm{m}$ screen. Treatment 4C examined the effects of 50:50 mixture (based on cell volume concentration measured with a Coulter counter (Vanderploeg et al. 1995)) of small colonies of LE-3 M. aeruginosa and Cryptomonas on mussel feeding.

\section{Results}

\section{Chlorophyll, phytoplankton composition, and microcystin in Saginaw Bay}

Zebra mussels started significantly recruiting to Saginaw Bay during the late summer and fall of 1991 (Nalepa et al. 1995). Monitoring results for 1992-1996 revealed that in every year except 1993, there was a dramatic clear-water phase in spring followed by relatively high $\mathrm{Chl} a$ concentration during the summer (Fig. 1). In 1993, the clear-water phase lasted throughout the summer.

In 1990, before the zebra mussels invaded the bay, the cyanobacterium Oscillatoria comprised $35-40 \%$ of phytoplankton biomass during May and September, but it or other cyanobacteria were not found in October. In 1991, cyanobacteria were rare $(0-10 \%$ of the biomass) and Microcystis was not found. In contrast, $M$. aeruginosa was an important 
Table 1. Experimental conditions for zebra mussels feeding on naturally occurring Microcystis in seston from Saginaw Bay (SB) and Lake Erie (LE) on mixtures with $R$. minuta and C. ozolini.

\begin{tabular}{|c|c|c|c|c|c|c|c|}
\hline \multirow[b]{2}{*}{ Experiment } & \multirow[b]{2}{*}{ Date } & \multirow{2}{*}{$\begin{array}{l}\text { Size fraction } \\
(\mu \mathrm{m})\end{array}$} & \multirow{2}{*}{$\begin{array}{l}\bar{C}_{\mathrm{wc}} \\
\left(\mu \mathrm{g} \cdot \mathrm{L}^{-1}\right)\end{array}$} & \multirow{2}{*}{$\begin{array}{l}\text { Microcystis } \\
\text { biomass (\%) }\end{array}$} & \multirow{2}{*}{$\begin{array}{l}\text { Microcystin concentration in } \\
\text { Microcystis }\left(\mu \mathrm{g} \cdot \mu \mathrm{g} \mathrm{Chl} a^{-1}\right)\end{array}$} & \multicolumn{2}{|c|}{ 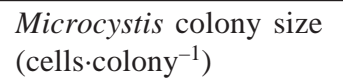 } \\
\hline & & & & & & Mean & Range \\
\hline \multirow[t]{3}{*}{ SB seston } & 11 July 1995 & $<53$ & 4.4 & & & & \\
\hline & & $>53$ & 19.3 & 82 & & & \\
\hline & & Total & 23.7 & 67 & 0.25 & 2130 & $300-10000$ \\
\hline \multirow[t]{3}{*}{ SB seston $>53 \mu \mathrm{m}+$ Rhodmonas } & 12 July 1995 & $<53$ & 6.1 & & & & \\
\hline & & $>53$ & 17.1 & 82 & 0.25 & 2130 & $300-10000$ \\
\hline & & Total & 23.2 & & & & \\
\hline \multirow[t]{3}{*}{ LE seston } & 21 Sept. 1995 & $<53$ & 1.3 & & & & \\
\hline & & $>53$ & 36.6 & & & & \\
\hline & & Total & 37.9 & 76 & & 3230 & $800-10000$ \\
\hline \multirow[t]{3}{*}{ LE seston + Rhodmonas } & 22 Sept. 1995 & $<53$ & 3.5 & & & & \\
\hline & & $>53$ & 16.6 & & & & \\
\hline & & Total & 20.1 & 76 & & 3230 & $800-10000$ \\
\hline \multirow[t]{3}{*}{ SB seston $>153 \mu \mathrm{m}+$ Cryptomonas } & 15 Aug. 1997 & $<53$ & 2.8 & & & & \\
\hline & & $>53$ & 1.9 & 99 & 0.30 & 1320 & $200-4500$ \\
\hline & & Total & 4.9 & & & & \\
\hline \multirow[t]{3}{*}{ SB seston $53-153 \mu \mathrm{m}+$ Cryptomonas } & 15 Aug. 1997 & $<53$ & 3.2 & & & & \\
\hline & & $>53$ & 1.7 & 82 & 0.30 & 207 & $20-700$ \\
\hline & & Total & 4.9 & & & & \\
\hline
\end{tabular}

Note: $\bar{C}_{\mathrm{wc}}$ is the average $\mathrm{Chl} a$ concentration available to the mussels during the experiment; $\mathrm{SE} / \bar{X}$ was in all cases $<5 \%$. All experiments were run at $20-21^{\circ} \mathrm{C}$. 
Table 2. Experimental conditions for zebra mussels grazing on different $M$. aeruginosa strains and $C$. ozolini offered alone or together.

\begin{tabular}{|c|c|c|c|c|c|c|}
\hline Strain or mixture and comments & Experiment & $\begin{array}{l}\text { Acclimation } \\
\text { period }(\mathrm{h})\end{array}$ & $\begin{array}{l}\text { Temperature } \\
\left({ }^{\circ} \mathrm{C}\right)\end{array}$ & $\begin{array}{l}\text { Microcystin } \\
\text { concentration } \\
\left(\mu \mathrm{g} \cdot \mu \mathrm{g} \mathrm{Chl} a^{-1}\right)\end{array}$ & $\begin{array}{l}\text { Size fraction } \\
(\mu \mathrm{m})\end{array}$ & $\begin{array}{l}\bar{C}_{\mathrm{wc}} \\
\left(\mu \mathrm{g} \cdot \mathrm{L}^{-1}\right)\end{array}$ \\
\hline \multirow[t]{3}{*}{ CCAP $1450 / 11^{a}$} & 1 & 4 & 25 & 0 & $<53$ & 10.8 \\
\hline & & & & & $>53$ & 1.0 \\
\hline & & & & & Total & 11.8 \\
\hline PCC $7820^{b}$ & 2 & 70 & 17 & 0.22 & $<53$ & 3.9 \\
\hline${\mathrm{LE}-3^{c}}^{c}(<53 \mu \mathrm{m})$ & $3 \mathrm{~A}$ & 18 & 20 & 0.66 & Total $^{e}$ & 5.6 \\
\hline \multirow[t]{3}{*}{ LE-3c } & $3 \mathrm{~B}$ & 2 & 20 & 0.66 & $<53$ & 0.8 \\
\hline & & & & & $>53$ & 0.7 \\
\hline & & & & & Total & 1.5 \\
\hline Cryptomonas & $3 \mathrm{C}$ & 1 & 20 & 0 & Total $^{e}$ & 7.8 \\
\hline Cryptomonas & $4 \mathrm{~A}$ & 18 & 20 & 0 & Total $^{e}$ & 3.0 \\
\hline
\end{tabular}

Note: Experiments with same number but different letter designations were run with the same mussels on the same or consecutive days in the indicated order. LE-3 $(<53)$ refers to the LE-3 strain that was poured through a screen to produce colonies $\left\langle 53 \mu \mathrm{m} ; \bar{C}_{\text {wc }}\right.$ is the average Chl $a$ concentration available to the mussels during the experiment; $\mathrm{SE} / \bar{X}$ was in all cases $<5 \%$.

${ }^{a}$ Culture Collection of Algae and Protozoa, Ambleside, U.K.

${ }^{b}$ Pasteur Culture Collection, Paris, France.

${ }^{c}$ Lake Erie isolate of Wayne Carmichael (Brittain et al. 2000).

${ }^{d}$ Microcystin concentration in Microcystis fraction.

${ }^{e}$ Cryptomonas or LE-3 Microcystis fell within the $<53 \mu \mathrm{m}$ size fraction.

Fig. 1. Seasonal chlorophyll concentrations at Station 5 in Saginaw Bay during years before and after zebra mussels invaded Saginaw Bay. Data are means that have a precision $(\mathrm{SE} / \bar{X})$ of better than $5 \%$.

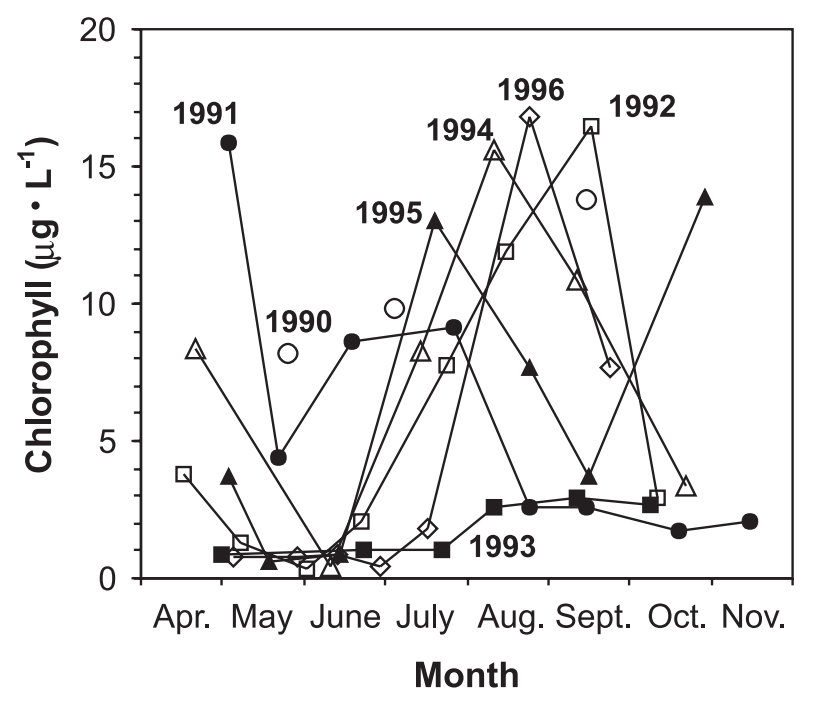

component ( $>40 \%$ of biomass on at least one date) of the algal community during 1992, 1994, and 1995 and tended to dominate during summer and early fall (Fig. 2). During blooms in Saginaw Bay and Lake Erie, the colonies were quite large, having $300-10000$ cells $\cdot$ colony $^{-1}$ (Table 1). During nonbloom periods, colonies were smaller (Tables 1 and 3); however, in all cases, $M$. aeruginosa was primarily found in the $>53 \mu \mathrm{m}$ size fraction. At all times sampled (Tables 1 and 3), M. aeruginosa was toxic, and during experi- ments, microcystin concentration was about the same (Table 1). Although the microcystin concentration in the Lake Erie bloom was not measured, the isolate from the bloom had a high concentration of microcystin (Table 2). In September 1992, other gelatinous colony-forming cyanophytes, Agmenellum and Synechococcus, combined with Microcystis to account for $80 \%$ of the algal community.

\section{Experiments with natural seston}

The mussels in all experiments except the SB experiment (with unmodified seston) exhibited high values of $F(<53)$ that were significantly different from zero (Fig. $3 a$ ). A similar pattern was seen for $F_{\mathrm{A}}(<53)$, except that $F_{\mathrm{A}}(<53)$ was appreciably lower than $F_{(<53)}$ in the LE experiment. In contrast, $F(>53)$ was low and $F_{\mathrm{A}}(>53)$ was very low (Fig. 3 ) in all experiments. Only in the case of the experiment "SB seston 53-153 $\mu \mathrm{m}+$ Cryptomonas" were both $F(>53)$ and $F_{\mathrm{A}}(>53)$ significantly different from zero. Since $M$. aeruginosa dominated the $>53 \mu \mathrm{m}$ fraction (Table 1), this implied that the response to the $>53 \mu \mathrm{m}$ fraction represented the response to Microcystis. That $F(>53)$ was much less than $F(<53)$ implied that an appreciable portion of CR not assimilated was returned to the water column under the mixing regime of this experiment. The low or zero values of $F_{\mathrm{A}}(>53)$ (relative to high values of $\left.F_{\mathrm{A}}(<53)\right)$ imply very low or zero selectivity for the $M$. aeruginosa colonies.

The high values of $F(<53)$ (= pumping rate) and the very high concentrations of Chl $a$ in the $>53 \mu \mathrm{m}$ fraction in the "SB seston > $53 \mu \mathrm{m}+$ Rhodomonas," "LE seston," and "LE seston + Rhodomonas" experiments (Table 1) led to very high CRs (CR $=200-380 \%$ C.day-1, Fig. 3c), most of which was not assimilated (Fig. 3d) but, as shown by video observations, was expelled in the form of pseudofeces primarily composed 
Fig. 2. Seasonal phytoplankton composition expressed as relative carbon biomass at Station 5 in Saginaw Bay during years of Microcystis dominance.
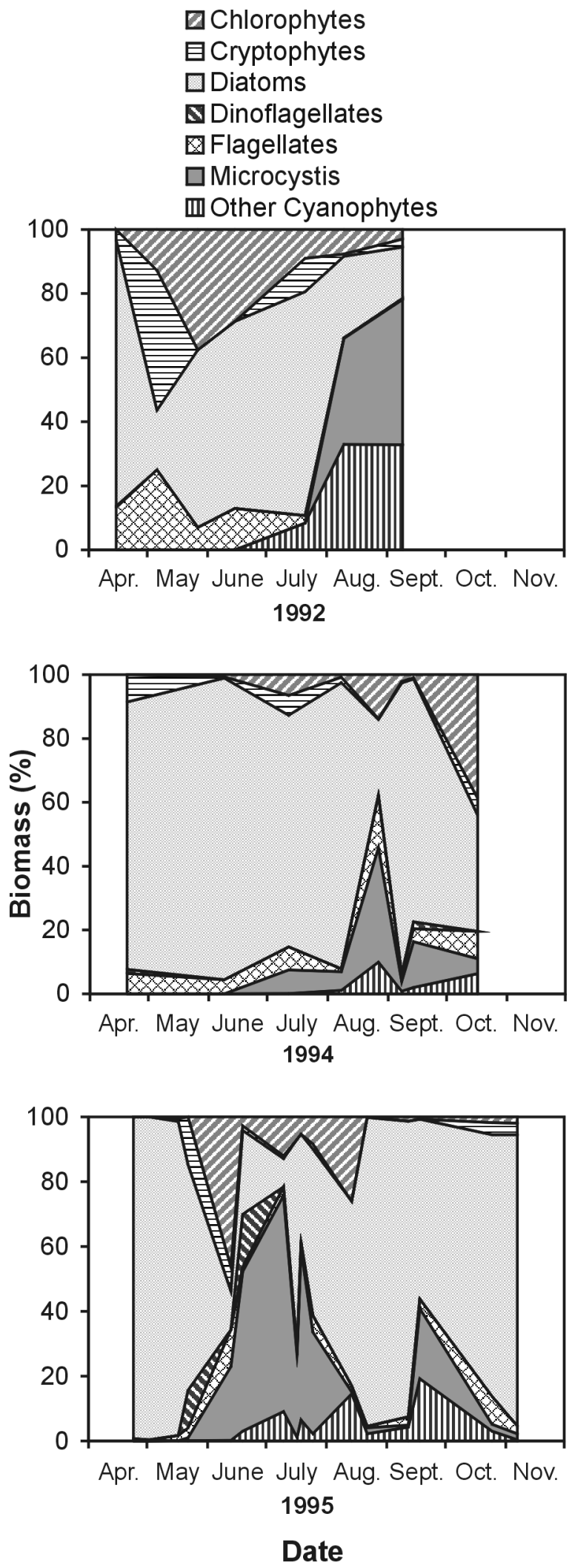

of Microcystis colonies (H.A. Vanderploeg, unpublished data). These pseudofeces were very unconsolidated, a mass of loosely aggregated colonies that tended to break down into their constituent colonies as they were expelled from the incurrent siphon (H.A. Vanderploeg, unpublished data).

Large and significant values of $A$ were in all cases due to the large contribution of $A(<53)$. Because $A$ is the product of filtering rate and $\mathrm{Chl} a$ concentration (eq. 5), the large but not significant values of $A(>53)$ and $A$ for the LE experiment were due to the product of low but variable $F_{\mathrm{A}}(>53)$ values (Fig. $3 b$ ) and very large Chl $a$ concentrations in the $>53 \mu \mathrm{m}$ size fraction (Table 1).

\section{Experiments with laboratory cultures}

Mussels exhibited high values of $F, F_{\mathrm{A}}$, and $A$ when feeding on the toxic (Table 2) PCC 7820 strain of $M$. aeruginosa (Experiment 2, Fig. 4). The $F(<53), \quad F(>53), \quad F_{\mathrm{A}}(<53)$, $F_{\mathrm{A}}(>53)$, and $A$ of PCC 7820 were all equal to or greater than the respective values of for Cryptomonas in the other experiments (Fig. 4). Thus, the mussels treated this toxic strain as a preferred food, and selectivity $\left(F_{\mathrm{A}}\right)$ for large colonies $(>53 \mu \mathrm{m})$ was nearly as high as for small colonies $(<53 \mu \mathrm{m})$.

The $F$ and $F_{\mathrm{A}}$ of the nontoxic CCAP 1450/11 strain (Table 2) were considerably lower than the respective values for PCC 7820 (Fig. 4). Both $F(>53)$ and $F_{\mathrm{A}}(>53)$ of the CCAP $1450 / 11$ strain were negative, and $F(<53)$ and $F_{\mathrm{A}}(<53)$ were considerably lower than the respective values for PCC 7820 or Cryptomonas; however, $A$ was about the same. Much of the material filtered was ingested because both $\mathrm{CR}$ and $A$ had similar values. In Experiment $3, F, F_{\mathrm{A}}$, and $A$ were low or not significantly different from zero for the LE-3 strain of Microcystis, whether presented as colonies $<53 \mu \mathrm{m}$ (Treatment 3A) or distributed between size-classes (Treatment 3B) (Fig. 4; Table 2). In contrast, after only $1 \mathrm{~h}$ of acclimation, $F$, $F_{\mathrm{A}}$, and $A$ were high for Cryptomonas (Treatment 3C, Fig. 4). In Experiment $4, F, F_{\mathrm{A}}$, and $A$ were high for Cryptomonas, not significantly different from zero for the LE-3 strain of Microcystis, and low for the mixture of the LE-3 strain of Microcystis plus Cryptomonas (Fig. 4).

\section{Discussion}

\section{Strain- and size-specific response}

Mussel response to $M$. aeruginosa was strain specific. The toxic PCC 7820 and nontoxic CCAP 1450/11 strains were readily filtered $\left(F_{\mathrm{A}}\right)$ or assimilated $(A)$ at rates comparable with those of Cryptomonas, a highly desirable food. It seems probable that low $F(<53)$ and $F_{\mathrm{A}}(<53)$ values for the CCAP 1450/11 strain of $M$. aeruginosa resulted from the Chl $a$ concentration in this experiment being above the incipient limiting concentration (ILC). Sprung and Rose (1988) found that the ILC for zebra mussels feeding on Chlamydomonas expressed in algal volume units was $\sim 2 \mathrm{~mm}^{3} \cdot \mathrm{L}^{-1}$; average concentration of CCAP 1450/11 was equivalent to $7.2 \mathrm{~mm}^{3} \cdot \mathrm{L}^{-1}$. It is also possible that there was some inhibition of filtering rate due to this culture being in early stationary phase rather than exponential phase as were all other cultures. The negative values of $F(>53)$ and $F_{\mathrm{A}}(>53)$ probably do not indicate a lack of ingestion of colonies in the $>53 \mu \mathrm{m}$ fraction. Instead, this is probably a typical case of the particle-production problem that arises when high food 
Table 3. Colony size and microcystin concentration of M. aeruginosa at Station 5 in Saginaw Bay.

\begin{tabular}{lcclll}
\hline & \multicolumn{2}{l}{ Microcystis colony size $\left(\right.$ cells $\cdot$ colony $\left.^{-1}\right)$} & & \multicolumn{2}{l}{ Microcystin concentration } \\
\cline { 2 - 3 } Date & Mean & Range & & Water $\left(\mu \mathrm{g} \cdot \mathrm{L}^{-1}\right)$ & Microcystis $\left(\mu \mathrm{g} \cdot \mu \mathrm{g} \mathrm{Chl} a^{-1}\right)$ \\
\hline 20 June 1995 & 691 & $100-1000$ & & 0.10 & 0.14 \\
11 July 1995 & 2130 & $300-10000$ & & 3.5 & 0.25 \\
15 Aug. 1995 & 71 & $50-100$ & & 0.10 & 0.20 \\
\hline
\end{tabular}

Note: Values for water are totals for the particulate phase.

Fig. 3. Effect of naturally occurring $M$. aeruginosa on $(a)$ filtering rates $(F),(b)$ filtering rates for assimilated chlorophyll $\left(F_{\mathrm{A}}\right)$, (c) capture rates $(\mathrm{CR})$, and $(d)$ assimilation rates $(A)$ in experiments (Table 1) with seston from Saginaw Bay (SB), Lake Erie (LE), and mixtures of seston and laboratory cultures of Rhodomonas (Rhod) and Cryptomonas (Crypt). In all cases, M. aeruginosa dominated the $>53 \mu \mathrm{m}$ size fraction. For each experiment, results are shown from left to right for $<53 \mu \mathrm{m}$ (open bars), >53 $\mu \mathrm{m}$ (hatched bars), and the total (shaded bars) size fractions. Means and standard errors for the four replicate experimental beakers are shown, and asterisks indicate values significantly different $(P<0.05)$ from zero.
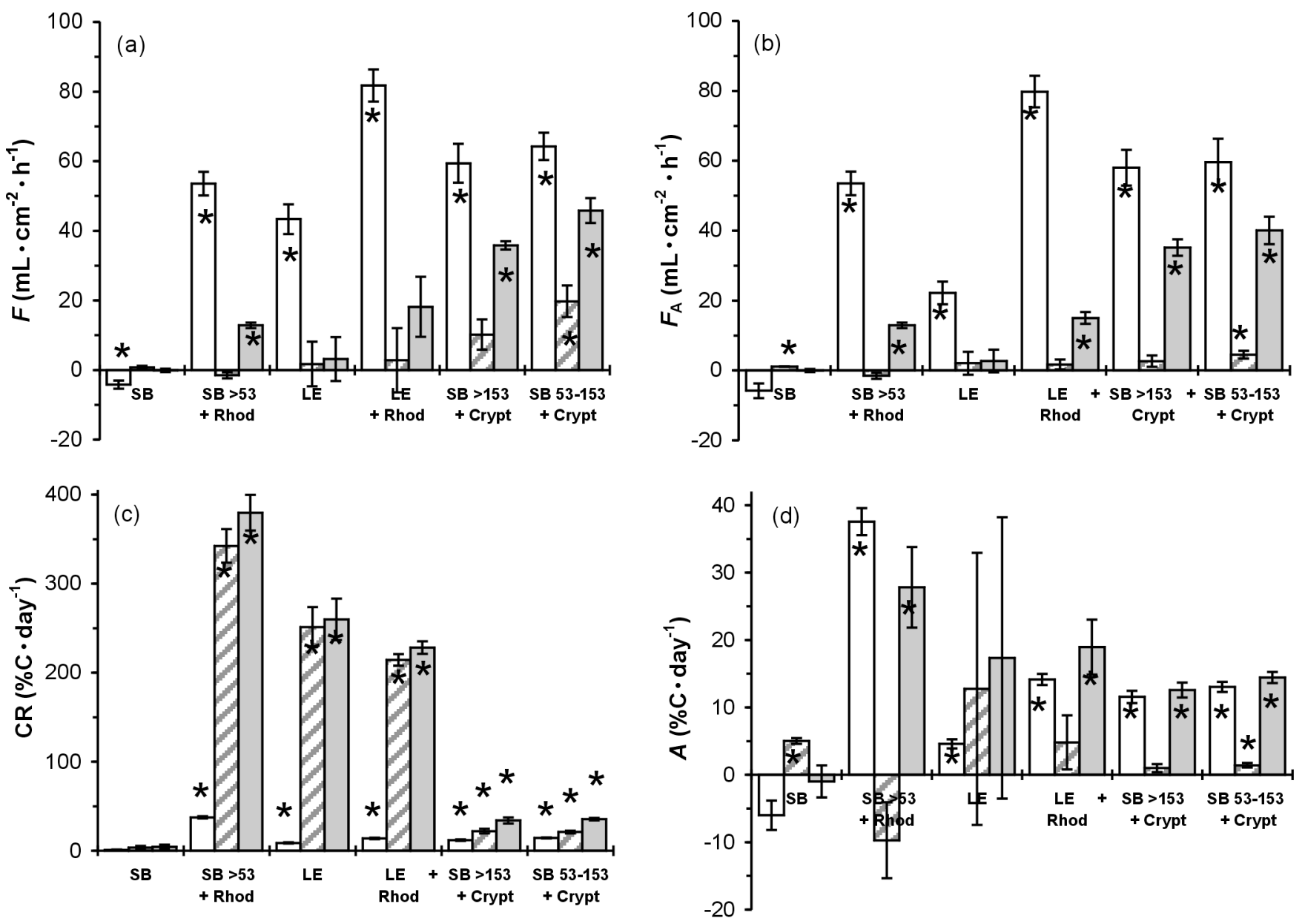

Treatment

concentration in one size category is transformed into particles in another size category having few particles to begin with (Vanderploeg et al. 1984). Here, concentration of Chl $a$ in the $>53 \mu \mathrm{m}$ fraction was very low, and high pseudofeces production resulting from high $\mathrm{CR}(<53)$ added much $\mathrm{Chl} a$ to the $>53 \mu \mathrm{m}$ fraction.

The $F_{\mathrm{A}}$ values for Cryptomonas and PCC 7820 (90$\left.100 \mathrm{~mL} \cdot \mathrm{cm}^{-2} \cdot \mathrm{h}^{-1}\right)$ correspond closely to the high filtering rate $\left(84-114 \mathrm{~mL} \cdot \mathrm{cm}^{-2} \cdot \mathrm{h}^{-1}\right)$ reported by Kryger and Riisgård (1988) for Chlorella at $20^{\circ} \mathrm{C}$ under "ideal" laboratory conditions. Assimilation rates of $30-40 \% \mathrm{C} \cdot \mathrm{day}^{-1}$ observed in our experiments for Cryptomonas and the PCC 7820 and CCAP
1450/11 strains of $M$. aeruginosa were considerably higher than the maximum of $4.5 \% \mathrm{C} \cdot \mathrm{day}^{-1}$ reported by Walz (1978) for the pennate diatom Nitzschia. The experiment with the PCC 7820 strain showed that both large and small size fractions of $M$. aeruginosa were ingested (and assimilated).

In contrast, $F_{\mathrm{A}}$ and $A$ of the small colonies of the LE-3 strain and large colonies of $M$. aeruginosa of Saginaw Bay or Lake Erie seston were low or zero. Since the LE-3 strain was isolated from the Lake Erie bloom, we can argue that Lake Erie $M$. aeruginosa of all sizes were unpalatable to the mussels. The $F_{\mathrm{A}}$ and $A$ of $M$. aeruginosa from Saginaw Bay were low, whether presented as that found in natural seston 
Fig. 4. (a) Filtering rates $(F)$, $(b)$ filtering rates for assimilated chlorophyll $\left(F_{\mathrm{A}}\right),(c)$ capture rates $(\mathrm{CR})$, and $(d)$ assimilation rates $(A)$ in four experiments (Table 2) with individual strains of $M$. aeruginosa in comparison with $C$. ozolini (Crypt) and in mixture to evaluate the effects of M. aeruginosa strain type and size. Microcystis aeruginosa strain types: CCAP, Culture Collection of Algae and Protozoa (Ambleside, U.K.) strain 1450/11; PCC, Pasteur Culture Collection (Paris, France) strain 7820; LE, LE-3 strain. The experiment numbers referred to in Table 2 are shown on the abscissa, and the uppercase letters refer to treatments within an experimental series with the same mussels. Means and standard errors for the four replicate experimental beakers are shown, and asterisks indicate values significantly different $(P<0.05)$ from zero. In experiments labeled CCAP (Experiment 1), PCC (Experiment 2), and LE (Treatment 3B), a broad size range of colonies (Table 2) was presented and results are given for <53 $\mu \mathrm{m}$ (open bars), >53 $\mu \mathrm{m}$ (hatched bars), and the total (shaded bars) size fractions. In experiments with small-sized colonies of LE-3 M. aeruginosa (labeled LE <53), C. ozolini (Crypt), or mixtures of Crypt and LE <53, all cells or colonies appeared in the $<53 \mu \mathrm{m}$ fraction and are presented as "total" results (shaded bars).
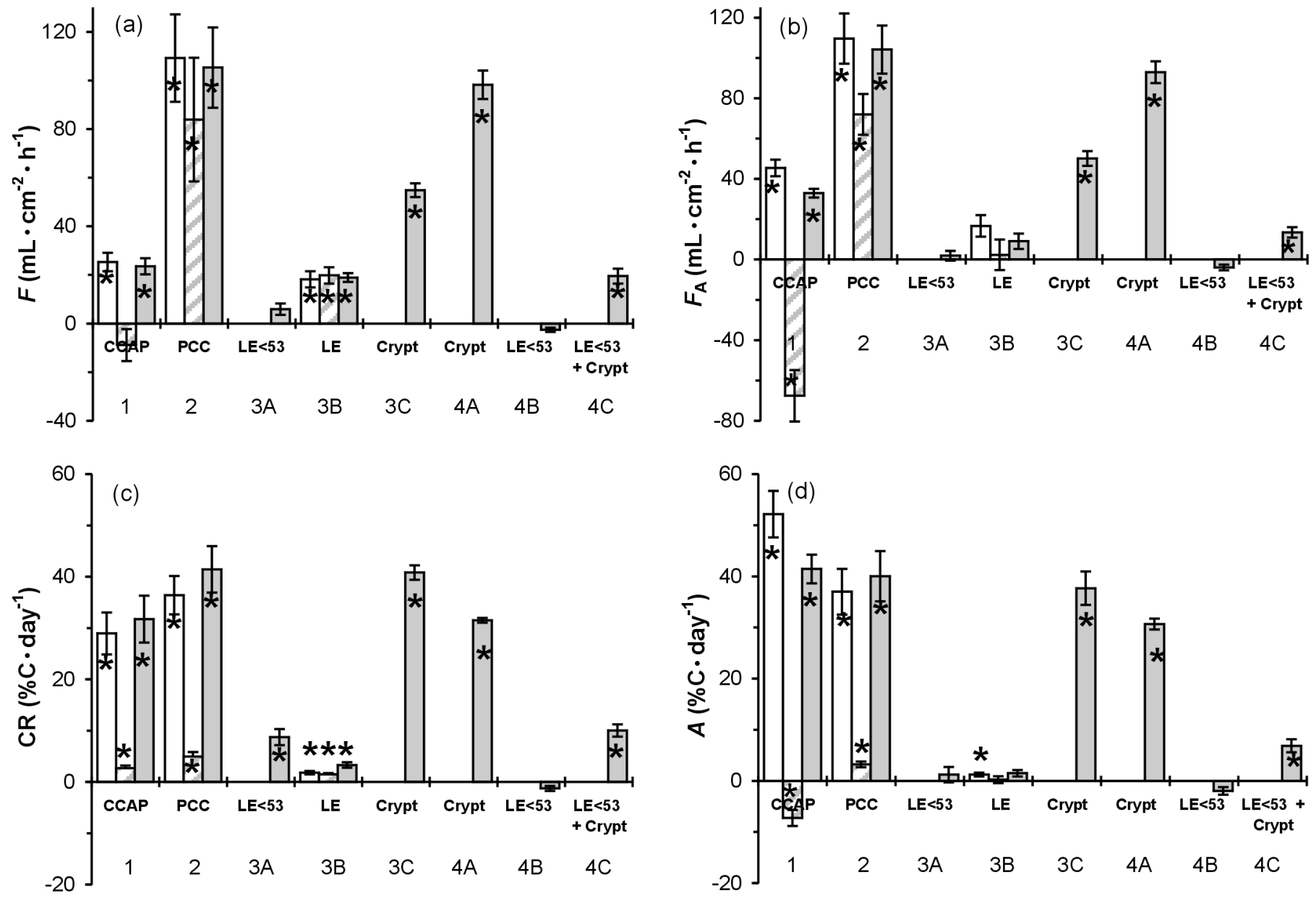

Treatment

or that in the restricted size ranges of 53-153 and >153 $\mu \mathrm{m}$. Experiments with other large colony-forming algal species and microzooplankton indicated that colonies in the size range of 53-153 $\mu \mathrm{m}$, although not filtered at maximal rates, would not present a great impediment to feeding (e.g., MacIsaac et al. 1991; Horgan and Mills 1997; Bastviken et al. 1998). Ten Winkel and Davids (1982) noted that algae as large as $750 \mu \mathrm{m}$ could be ingested. Thus, although it is possible that very large colonies may be impossible for Dreissena to ingest, chemical quality or toxicity was important to the mussels' response. Poor chemical quality was suggested as the reason for the much lower selectivity for $25-\mu \mathrm{m}$-diameter colonies of the cyanobacterium Chroococcus relative to algae of the same size (Ten Winkel and Davids 1982).

Experiments of Lavrentyev et al. (1995), Bastviken et al. (1998), and Baker et al. (1998) are consistent with our con- clusions of the importance of $M$. aeruginosa strain type on mussel response. Lavrentyev et al. (1995) observed zero net clearance rates on Microcystis in screened (40 and $53 \mu \mathrm{m})$ and unscreened Saginaw Bay seston in September and October 1994, when $40 \%$ of the algal biomass was Microcystis. Bastviken et al. (1998) showed that "net" clearance rate $\left(\sim F_{\mathrm{A}}\right)$ of natural colonial Microcystis (with greatest linear dimension of $49 \mu \mathrm{m}$ ) in Hudson River seston was about $25 \%$ of that of the preferred foods, which were ambient cryptophytes and unicellular cultured M. aeruginosa (Carolina Biological Supply) added to the seston.

In contrast, Baker et al. (1998) reported that unicells of the nontoxic UTEX 2386 and toxic UTEX 2385 strains of $M$. aeruginosa were cleared at a rate greater than green algae and diatoms. Clearance rates calculated for their $20-\mathrm{mm}$ mussels for the nontoxic strain were $\sim 45 \pm 2 \mathrm{~mL} \cdot \mathrm{cm}^{-2} \cdot \mathrm{h}^{-1}$ at 
$16^{\circ} \mathrm{C}$, which falls between the values reported for PCC 7820 and CCAP 1450/11. Respective concentrations of algae expressed on a volumetric basis were $3.4,2.3$, and $7.2 \mathrm{~mm}^{3} \cdot \mathrm{L}^{-1}$, where the first value refers to initial concentration and the other two are average concentrations from Table 2. Based on the expected lowered filtering rate due to an ILC of $\sim 2 \mathrm{~mm}^{3} \cdot \mathrm{L}^{-1}$ (Sprung and Rose 1988), these results represent feeding rates on desirable foods.

The low clearance rates that Baker et al. (1998) observed on green algae and diatoms were probably a result of their being above the ILC; the diatoms and green algae were much larger than Microcystis and all algae were presented at a high initial concentration $\left(10^{5}\right.$ cells $\left.\cdot \mathrm{mL}^{-1}\right)$. In the case of the diatom Cyclotella, the initial concentration of $10^{5}$ cells $\cdot \mathrm{mL}^{-1}$ corresponds to $52 \mathrm{~mm}^{3} \cdot \mathrm{L}^{-1}$.

\section{Role of microcystin}

Microcystin concentrations in $M$. aeruginosa from Saginaw Bay were midrange $\left(0.14-0.30 \mu \mathrm{g} \mu \mathrm{g} \mathrm{Chl} a^{-1}\right)$ of values reported for $M$. aeruginosa in German Lakes (Sivonen and Jones 1999). The 11 July 1995 microcystin concentration of $3.5 \mu \mathrm{g} \cdot \mathrm{L}^{-1}$ in Saginaw Bay was the highest concentration found in the particulate phase in our study of Saginaw Bay. Much higher concentrations $\left(10-100 \mu \mathrm{g} \cdot \mathrm{L}^{-1}\right)$ have been found in more eutrophic systems with higher Microcystis concentrations (Sivonen and Jones 1999). If the microcystin content of the LE-3 strain were representative of M. aeruginosa in Lake Erie from which it was isolated, the toxin concentration found in Lake Erie Microcystis in September 1995 would have been estimated at $24 \mu \mathrm{g} \cdot \mathrm{L}^{-1}$ and would have fallen within the high end of the range reported for lakes (Sivonen and Jones 1999).

The high values of $F_{\mathrm{A}}$ and $A$ for PCC 7820 were surprising given its well known tendency to "block" ingestion in Daphnia and cause rapid mortality from the small amount ingested (Nizan et al. 1986). PCC 7820 is also known to be toxic in mouse bioassays, and its extracts are toxic to copepods, which normally reject it and thus avoid ingestion (DeMott and Moxter 1991). The toxic strain used by Baker et al. (1998) was less potent than PCC 7820 in that ingestion was not as much suppressed in Daphnia and survival was high (Nizan et al. 1986). It would be tempting to explain Dreissena's low $F_{\mathrm{A}}$ and $A$ on the LE-3 isolate from Lake Erie to be a result of its high microcystin concentrations relative to other strains. However, it has been argued that toxicity of Microcystis to zooplankton may not be actually caused by microcystin but another secondary compound termed Daphnia-toxic compound (DTC) (Jungmann and Benndorf 1994). In addition, the rejected $M$. aeruginosa from Saginaw Bay had a microcystin concentration about the same as that for PCC 7820.

Perhaps the low values of $F(<53)$ and $F_{\mathrm{A}}(<53)$ of the mussels in Saginaw Bay seston represented a chronic effect of a long-term exposure to a high concentration of toxic Microcystis. Toxic Microcystis had dominated the algal community at Station 5 in Saginaw Bay for 3 weeks before this experiment. Video observations showed that in this experiment, the mussels were actively filtering only $54 \%$ if the time whereas in all other experiments, including the one with Saginaw Bay seston enriched with Rhodomonas, were filtering 93-97\% of the time (H.A. Vanderploeg, unpublished data).

\section{Sorting abilities of mussels}

The depression of feeding rate seen in the mixture of LE-3 Microcystis and Cryptomonas (Experiment 4) probably indicates an inability to sort out small Microcystis colonies from Cryptomonas. The depression in filtering rate was also seen in mussel feeding activity (H.A. Vanderploeg, unpublished observations). Mussels exposed to Cryptomonas alone were actively filtering $92 \%$ of the time whereas they were filtering only $41-52 \%$ of the time when given small LE-3 Microcystis colonies or the LE-3 Microcystis + Cryptomonas mixture, and few pseudofeces were produced (H.A. Vanderploeg, unpublished data).

Mussels do have the ability to sort out different particles and even different algal species. Ward et al. (1998) showed that the marine mussel Mytilus can sort out detritus of Spartina $(3-20 \mu \mathrm{m})$ from similarly sized Rhodomonas (6$13 \mu \mathrm{m})$ and enrich the pseudofeces with a higher concentration of Spartina relative to Rhodomonas. Baker et al. (1998) showed that when various high concentration mixtures of large green algae and diatoms were presented to mussels with small unicells of nontoxic $M$. aeruginosa, the pseudofeces were enriched with the large algae relative to Microcystis. Furthermore, as noted above, zebra mussels had a lower selectivity for $25-\mu \mathrm{m}$-diameter Chroococcus relative to other algae of the same size (Ten Winkel and Davids 1982). However, no one has shown that small (4-6 $\mu \mathrm{m})$ algal species of nearly the same size can be sorted. The depression in feeding rate in mussels was similar to that in filter-feeding cladocerans when Microcystis was paired with similar-sized desirable green algae (Lampert 1982; Fulton and Paerl 1987). It is unknown how much of the small colonies of Microcystis, relative to other food, is required to cause a significant drop in mussel feeding.

\section{Ecosystem implications}

\section{Did zebra mussel grazing promote toxic Microcystis dominance?}

We do not have extensive series of algal community structure and toxin concentration for either Saginaw Bay or Lake Erie that cover a long period before and after the zebra mussel invasions; however, some information is available. In 1990 and 1991, before zebra mussel dominance in Saginaw Bay, Microcystis was not abundant. Microcystis aeruginosa dominated the algal community of Saginaw Bay during 1992, during brief periods during 1994, and for much of the summer during 1995. In all times sampled in 1995, M. aeruginosa contained microcystin. Synechococcus was also present in September 1992 and it, in addition to $M$. aeruginosa, could have been toxic because it is a known microcystin producer (Domingos et al. 1999). Furthermore, it is possible that our estimates of Microcystis abundance may be underestimated. Lavrentyev et al. (1995) reported that Microcystis dominated $40 \%$ of the algal community in September and October 1994, and our 30-cm-diameter 64$\mu \mathrm{m}$-mesh plankton nets were clogged with large Microcystis colonies that may not have been adequately sampled by the 2-50 mL subsampled for making phytoplankton slides. Thus, Microcystis was not a dominant part of the phyto- 
Table 4. Dreissena polymorpha biomass (Nalepa et al. 1999; T.F. Nalepa, unpublished data) and grazing impact on desirable algae expressed as the fraction of the water column cleared (= mortality rate coefficient) in the inner portion of Saginaw Bay assuming a clearance rate of $10-30 \mathrm{~mL} \cdot \mathrm{mg}^{-1} \cdot \mathrm{h}^{-1}\left(\approx 38-129 \mathrm{~mL} \cdot \mathrm{cm}^{-2} \cdot \mathrm{day}^{-1}\right.$ for mussels in our study), which were typical low and high values measured there by Fanslow et al. (1995).

\begin{tabular}{llllll}
\hline & \multicolumn{1}{l}{ Year } \\
\cline { 2 - 6 } Variable & 1992 & 1993 & 1994 & 1995 & 1996 \\
\hline Biomass $\left(\mathrm{g} \cdot \mathrm{m}^{-2}\right)$ & 43.33 & 3.15 & 2.17 & 2.87 & 9.38 \\
Fraction of water column cleared $\left(\right.$ day $\left.^{-1}\right)$ & $2.04-6.12$ & $0.15-0.45$ & $0.10-0.30$ & $0.14-0.42$ & $0.44-1.32$ \\
\hline
\end{tabular}

plankton community 2 years before the invasion and was an important part three out five summers following the zebra mussel invasion.

In Lake Erie, cyanobacteria were a minor component of the phytoplankton before (1985-1987) and during the early expansion of the zebra mussel population (1988-1990) (Nicholls and Hopkins 1993). No Microcystis bloom of the magnitude of that occurring during September 1995 had occurred in the few years before or after this bloom. Such a bloom would have been obvious from shore or satellite imagery. These data from both Saginaw Bay and Lake Erie are consistent with mussels increasing the probability of a bloom, but Microcystis blooms are not a certainty.

Whether or not zebra mussels were responsible for Microcystis bloom promotion, they were not capable of controlling Microcystis concentrations. Marine mussels have been described as ecosystem stabilizers and eutrophication controllers (Herman and Scholten 1990) through their control of phytoplankton concentration by grazing. This control of phytoplankton concentration and resultant water clarity is often mentioned as ecosystem impacts of zebra mussels (e.g., Fahnenstiel et al. 1995; Caraco et al. 1997; Smith et al. 1998). Microcystis dominance in Saginaw Bay and Lake Erie and high summer chlorophyll concentrations in Saginaw Bay serve as a cautionary tale for the ideas of ecosystem stabilization or eutrophication control.

We estimated the potential collective impact of zebra mussels on mortality rate of desirable algae by calculating the fraction of water cleared (= mortality rate coefficient) by the mussels per day in the inner bay region of Saginaw Bay using biomass of mussels and weight-specific filtering rates given by Fanslow et al. (1995). Using a range of realistic upper and lower values of weight-specific filtering rates from Fanslow et al. (1995) resulted in mortality rate coefficients ranging between 0.10 and $6.12 \cdot$ day $^{-1}$ over the study period (Table 4). Typical specific growth rates of phytoplankton in natural systems range between 0.2 and $0.5 \cdot$ day $^{-1}$ in nutrientlimited systems with a maximum between 1 and $2 \cdot \mathrm{day}^{-1}$ where nutrients are not limiting (Reynolds 1997). Measured specific growth rates in Saginaw Bay were 0.20-0.25. day ${ }^{-1}$ (Fahnenstiel et al. 1995). Since most of the mortality rates were in the range of specific growth rates or greater, mussel grazing could have been an important force in promoting Microcystis and other grazing-resistant cyanophytes and algae. In Saginaw Bay, mussels had the strongest hypothetical grazing impact on mortality during 1992, which was the first year the mussels were there in all seasons and the biomass was high. In 1994 and 1995, values were more modest but were about the same as algal growth rate. However, in the nonbloom years of 1993 and 1996, calculated grazing impact was also appreciable. The potential impact of mussel grazing was also high in western Lake Erie, where Bunt et al. (1993) estimated that mussel clearance of the water column was $0.4-1.0 \cdot \mathrm{day}^{-1}$, and a more recent estimate (H.A. Vanderploeg, unpublished data) puts it at $\sim 1 \cdot$ day $^{-1}$.

High filtering rates, which would favor the selection process for Microcystis, were dependent on composition of the algal community. Experiments with natural Microcystis showed that $F(<53)$ and $F_{\mathrm{A}}(<53)$ were greatest when cryptophytes were added to the seston. Particularly noteworthy is the zero or negative values of $F(<53)$ and $F_{\mathrm{A}}(<53)$ in the experiment with Saginaw Bay seston that became very high with the addition of Rhodomonas. If selective rejection was operating as a mechanism for dominance of Microcystis in July 1995 in Saginaw Bay, then filtering rates had to be higher at an earlier time. The relatively high $F(<53)$ and $F_{\mathrm{A}}(<53)$ for unmodified Lake Erie seston of 1995 probably follow because cryptophytes and various flagellates were the dominant component of the phytoplankton after Microcystis. Thus, composition of the algal community could have been a factor in whether a bloom occurred.

The production of loosely consolidated pseudofeces is consistent with the return of viable Microcystis to the water column for continued growth. Baker et al. (1998) showed that pseudofeces produced in various combinations of laboratory algal cultures, clay suspension, and laboratoryproduced detritus were diffuse. Moreover, they showed that the algae in the pseudofeces were alive and continued to grow when cultured.

Did zebra mussels select for a toxic grazing-resistant $\mathrm{M}$. aeruginosa strain?

That zebra mussels showed low filtering rates and negative behavioral responses to the LE-3 toxic strain but not to the PCC and UTEX toxic strains raises the possibility that there may have been a selection for a particularly toxic or unpalatable strain of $M$. aeruginosa in Lake Erie. This argument would also apply to Saginaw Bay, where $M$. aeruginosa was also toxic and unpalatable as measured by microcystin concentration and mussel response. It can be argued that this response is not just a question of microcystin content because the mussels would have ingested great quantities of microcystin in the experiments with the PCC 7820 strain. There was probably selection for large M. aeruginosa colonies because selective rejection was only efficient with large colonies.

Why were there no Microcystis blooms in the Hudson River and shallow Dutch lakes?

It is important to consider that other factors such as light intensity (Mur et al. 1999), nutrient ratios (e.g., Smith 1983), and water temperature (Robarts and Zohary 1987) can affect 
competitive interactions between Microcystis and other algae. It is not surprising that zebra mussel selective rejection did not lead to blooms of toxic nitrogen-fixing cyanobacteria such as Aphanizomenon and Anabaena, which would be favored under very low nitrogen to phosphorus ratios, because Lake Erie and Saginaw Bay have moderate and high ratios, respectively (Holland et al. 1995; Johengen et al. 1995). Blooms of large colonial Aphanizomenon have occurred in eutrophic (i.e., low nitrogen to phosphorus ratio) Oneida Lake in late summer and autumn since the establishment of the zebra mussel (Horgan and Mills 1997). Microcystis and many other cyanobacteria have growth optima above $25^{\circ} \mathrm{C}$, whereas green algae and diatoms have optima considerably below $25^{\circ} \mathrm{C}$ (Robarts and Zohary 1987). Thus, Microcystis blooms will occur only in summer and be favored by warmer temperatures.

It would seem puzzling at first that Microcystis has not dominated in certain other systems such as the Hudson River (Caraco et al. 1997; Smith et al. 1998) or shallow Dutch lakes (Reeders et al. 1989; Reeders and Bij de Vaate 1990) if zebra mussel grazing was the cause of blooms in other locations. The disappearance, rather than promotion, of Microcystis in the Hudson River (Smith et al. 1998) may be related to strain type. The maximum fraction of the water column cleared by the mussels was estimated to be $\sim 0.7 \cdot$ day $^{-1}$ (Caraco et al. 1997; Smith et al. 1998), which is an appreciable rate for affecting phytoplankton composition through selective rejection. As noted above, Bastviken et al. (1998) showed that Microcystis colonies from the Hudson River were grazed at rates that were $25 \%$ of the maximum rate for preferred algae. Thus, grazing may not have been a force to favor Microcystis, especially in view of its slower growth rate (Reynolds 1997). We cannot be sure of the relative roles of toxicity or size in this lack of rejection, since the colonies in the Hudson River were relatively small $(47 \mu \mathrm{m})$ and toxin concentration was not measured.

Was there less of a selective force for the development of large unpalatable Microcystis colonies in the Hudson River? Because Microcystis and other cyanobacteria are favored over green algae and diatoms at low light intensities, light intensity rather than zooplankton grazing, which shapes summer phytoplankton community structure in nondreissenid lakes (Sommer et al. 1986), may have been the primary selective force in this turbid freshwater estuary. Light intensity was relatively unaffected in Hudson River because suspended sediments, although removed and packaged up in feces and pseudofeces by the mussels, were resuspended in this highenergy environment (Caraco et al. 1997). If light intensity and not grazing was the selective force, then Microcystis in this system may not have been preadapted for grazing resistance.

The lack of Microcystis blooms in Dutch Lakes IJsselmeer and Markermeer following zebra mussel introduction simply may have been a result of mussels not having a great enough grazing impact in these eutrophic lakes. The fractions of water cleared by the mussels in Lakes IJsselmeer and Markermeer were 0.09 and $0.06 \cdot$ day $^{-1}$, respectively.

In addition to selection for grazing-resistant algae or cyanobacteria, mussel filtering might promote selection of rapidly growing species that can grow faster than the mortality imposed by mussel clearance of the water column. This strategy would be most effective where nutrient concentrations are sufficient to promote rapid algal growth. Perhaps this scenario sometimes occurs in western Lake Erie, where phosphorus concentration is higher than in Saginaw Bay (Holland et al. 1995; Johengen et al. 1995). We do not know enough about the relationship between nutrient concentration and standing stock of zebra mussels to predict grazing pressure in different systems to evaluate grazing resistance versus growth rate strategies. Possibly, the lower incidence of blooms in Lake Erie compared with Saginaw Bay results from success of the rapid-growth strategy in most years.

We have shown that Microcystis is selectively rejected by zebra mussels and that selective rejection can be a large selective force for Microcystis or other grazing-resistant algae and cyanobacteria in shallow systems where zebra mussel density is high. Because the selective rejection mechanism requires that Microcystis be returned to the water column, the mechanism would work best in turbulent systems such as large shallow bays and lakes.

\section{Acknowledgements}

This is GLERL publication No. 1196. We thank L. Babcock-Jackson for making available the LE-3 strain of Microcystis that she isolated from Lake Erie, J. Hageman for collecting mussels and water from Lake Erie, and L. Courtney for doing the phytoplankton counts. We thank the Lake Erie Protection Fund for financial support for experimental work with different Microcystis strains.

\section{References}

An, J., and Carmichael, W.W. 1994. Use of colorometric protein phosphatase inhibition assay and enzyme linked immunosorbent assay for the study of microcystins and nodularins. Toxicon, 32: 1495-1507.

Baker, S.M., Levington, J.S., Kurdziel, J.P., and Shumway, S.E. 1998. Selective feeding and biodeposition by zebra mussels and their relation to changes in phytoplankton composition and seston load. J. Shellfish Res. 17: 1207-1213.

Bastviken, D.T.E., Caraco, N.F., and Cole, J.J. 1998. Experimental measurements of zebra mussel (Dreissena polymorpha) impacts on phytoplankton community composition. Freshwater Biol. 39: 375-386.

Bierman, V.J., Jr., Dolan, D.M., Kasprzyk, R., and Clark, J.L. 1984. Retrospective analysis of the response of Saginaw Bay, Lake Huron, to reductions in phosphorus loadings. Environ. Sci. Technol. 18: 23-31.

Bowers, J.A. 1980. Feeding habits of Diaptomus ashlandi and Diaptomus sicilis in Lake Michigan. Int. Rev. Gesamten Hydrobiol. 65: 259-267.

Brittain, S.M, Wang, J., Babcock-Jackson, L., Carmichael, W.W., Rinehart, K.L., and Culver, D.L. 2000. Isolation and characterization of microcystins, cyclic heptapeptide hepatoxins from a Lake Erie strain of Microcystis aeruginosa. J. Gt. Lakes Res. 26: 241-249.

Budd, J.W., Beeton, A.M., Stumpf, R.P., Culver, D.A., and Kerfoot, W.C. 2001. Satellite observations of Microcystis blooms in western Lake Erie and Saginaw Bay, Lake Huron. Verh. Int. Ver. Limnol. 27. In press.

Bunt, C.M., MacIsaac, H.J., and Sprules, W.G. 1993. Pumping rates and projected filtering impacts of juvenile zebra mussels 
(Dreissena polymorpha) in western Lake Erie. Can. J. Fish. Aquat. Sci. 50: 1017-1022.

Caraco, N.F., Cole, J.J., Raymond, P.A., Strayer, D.L., Pace, M.L., Findlay, S.E.G., and. Fischer, D.T. 1997. Zebra mussel invasion in a large, turbid river: phytoplankton response to increased grazing. Ecology, 78: 588-602.

Carmichael, W.W. 1996. Toxic Microcystis and the environment. In Toxic Microcystis. Edited by M.F. Watanabe, K.H. Harada, W.W. Carmichael, and H. Fujiki. CRC Press, Boca Raton, Fla. pp. 1-11.

DeMott, W.R., and Moxter, F. 1991. Foraging on cyanobacteria by copepods: responses to chemical defenses and resource abundance. Ecology, 7: 1820-1834.

Domingos, P., Rubim, T.K., Molica, R.J.R., Azevedo, S.M.F.O., and Carmichael, W.W. 1999. First report of microcystin production in a nannoplanktonic cyanobacterium Synechococcus sp. Environ. Toxicol. 14: 31-36.

Fahnenstiel, G.L., Lang, G.A., Nalepa, T.F., and Johengen, T.H. 1995. Effects of zebra mussel (Dreissena polymorpha) colonization on water quality parameters in Saginaw Bay, Lake Huron. J. Gt. Lakes Res. 21: 435-448.

Fahnenstiel, G.L., Krause, A.E., McCormick, M.J., Carrick, H.J., and Schelske, C.L. 1998. The structure of the planktonic food web in the St. Lawrence Great Lakes. J. Gt. Lakes Res. 24: 531-554.

Fanslow, D.L, Nalepa, T.F., and Lang, G.A. 1995. Filtration rates of the zebra mussel (Dreissena polymorpha) on natural seston from Saginaw Bay, Lake Huron. J. Gt. Lakes Res. 21: 489-500.

Frost, B.W. 1972. Effects of size and concentration of food particles on the feeding behavior of the marine planktonic copepod Calanus pacificus. Limnol. Oceanogr. 17: 805-815.

Fulton, R.S., III, and Paerl, H.W. 1987. Toxic and inhibitory effects of the blue-green alga Microcystis aeruginosa on herbivorous zooplankton. J. Plankton Res. 9: 837-855.

Herman, M.J., and Scholten, H. 1990. Can suspension feeders stabilize estuarine ecosystems? In Trophic relationships in the marine environment. Edited by M. Barnes and R.N. Gibson. Aberdeen University Press, Aberdeen, U.K. pp. 104-116.

Holland, R.E., Johengen, T.H., and Beeton, A.M. 1995. Trends in nutrient concentrations in Hatchery Bay, western Lake Erie, before and after Dreissena polymorpha. Can. J. Fish. Aquat. Sci. 52: 1202-1209.

Horgan, M.J., and Mills, E.L. 1997. Clearance rates and filtering activity of zebra mussel (Dreissena polymorpha): implications for freshwater lakes. Can. J. Fish. Aquat. Sci. 54: 249-255.

Johengen, T.H., Nalepa, T.F., Fahnenstiel, G.L., and Goudy, G. 1995. Nutrient changes in Saginaw Bay, Lake Huron, after the establishment of the zebra mussel (Dreissena polymorpha). J. Gt. Lakes Res. 21: 449-464.

Jungmann, D., and Benndorf, J. 1994. Toxicity to Daphnia of a compound extracted from laboratory and natural Microcystis spp., and the role of microcystins. Freshwater Biol. 32: 13-20.

Kryger, J., and Riisgård, H.U. 1988. Filtration rate capacities in 6 species of European freshwater bivalves. Oecologia, 77: 34-38.

Lampert, W. 1982. Further studies on the inhibitory effect of the toxic blue-green Microcystis aeruginosa on the filtering rate of zooplankton. Arch. Hydrobiol. 95: 207-220.

Lavrentyev, P.J., Gardner, W.S., Cavaletto, J.F., and Beaver, J.R. 1995. Effects of the zebra mussel (Dreissena polymorpha Pallas) on protozoa and phytoplankton from Saginaw Bay, Lake Huron. J. Gt. Lakes Res. 21: 545-557.

Lei, J., Payne, B.S., and Wang, S.Y. 1996. Filtration dynamics of the zebra mussel, Dreissena polymorpha. Can. J. Fish. Aquat. Sci. 53: 29-37.

MacIsaac, H.J., Sprules, W.G., and Leach, J.H. 1991. Ingestion of small-bodied zooplankton by zebra mussels (Dreissena poly- morpha): can cannibalism on larvae influence population dynamics? Can. J. Fish. Aquat. Sci. 48: 2051-2060.

Makarewicz, J.C. 1993. Phytoplankton biomass and species composition in Lake Erie, 1970 to 1987. J. Gt. Lakes Res. 19: 258-274.

Mur, L.R., Skulberg, O.M., and Utkilen, H. 1999. Cyanobacteria in the environment. In Toxic cyanobacteria in water. Edited by I. Chorus and J. Bartram. E\&FN Spon, London, U.K. pp. 15-40.

Nalepa, T.F., Cavaletto, J.F., Ford, M., Gordon, W.M., and Wimmer, M. 1993. Seasonal and annual variation in weight and biochemical content of the zebra mussel, Dreissena polymorpha, in Lake St. Clair. J. Gt. Lakes Res. 19: 541-552.

Nalepa, T.F., Wojcik, J.A., Fanslow, D.L., and Lang, G.A. 1995. Initial colonization of the zebra mussel (Dreissena polymorpha) in Saginaw Bay, Lake Huron: population recruitment, density, and size structure. J. Gt. Lakes Res. 21: 417-434.

Nalepa, T.F., Fahnenstiel, G.L., McCormick, M.J., Johengen, T.H., Lang, G.A, Cavaletto, J.F., and Goudy, G. 1996. Physical and chemical variables in Saginaw Bay, Lake Huron in 1991-93. NOAA Tech. Memo. ERL GLERL-91.

Nalepa, T.F., Fahnenstiel, G.L., and Johengen, T.H. 1999. Impacts of the zebra mussel (Dreissena polymorpha) on water quality: a case study of Saginaw Bay, Lake Huron. In Nonindigenous freshwater organisms: vectors, biology, and impacts. Edited by R. Claudi and J.H. Leach. Lewis Publishers, Boca Raton, Fla. pp. 255-271.

Nicholls, K., and Hopkins, G.J. 1993. Recent changes in Lake Erie (north shore) phytoplankton: cumulative impacts of phosphorus loading reduction and the zebra mussel introduction. J. Gt. Lakes Res. 19: 637-647.

Nizan, S., Dimentman, C., and Shilo, M. 1986. Acute toxic effects of the cyanobacterium Microcystis aeruginosa on Daphnia magna. Limnol. Oceanogr. 31: 497-502.

Reeders, H.H., and Bij de Vaate, A. 1990. Zebra mussels (Dreissena polymorpha): a new perspective for water quality management. Hydrobiologia, 200/201: 437-450.

Reeders, H.H., Bij de Vaate, A., and Slim, F.J. 1989. The filtration rate of Dreissena polymorpha (Bivalvia) in three Dutch lakes with reference to biological water quality management. Freshwater Biol. 22: 133-141.

Reynolds, C.S. 1997. Vegetation processes in the pelagic: a model for ecosystem theory. Oldendorf/Luhe, Germany.

Rippka, R., and Herdman, M. 1992. Pasteur culture collection of cyanobacteria catalog \& taxonomic handbook. Vol. I. Catalogue of strains. Institute Pasteur, Paris, France.

Robarts, R.D., and Zohary, T. 1987. Temperature effects on photosynthetic capacity, respiration, and growth rates of bloom-forming cyanobacteria. N.Z. J. Mar. Freshwater Res. 21: 391-399.

Schertzer, W.M., Saylor, J.H., Boyce, F.M., Robertson, D.G., and Rosa, F. 1987. Seasonal thermal cycle of Lake Erie. J. Gt. Lakes Res. 13: 468-486.

Sivonen, K., and Jones, G. 1999. Cyanobacterial toxins. In Toxic cyanobacteria in water. Edited by I. Chorus and J. Bartram. E\&FN Spon, London, U.K. pp. 41-111.

Smith, T.E., Stevenson, R.J., Caraco, N.F., and Cole, J.J. 1998. Changes in phytoplankton community structure during the zebra mussel (Dreissena polymorpha) invasion of the Hudson River (New York). J. Plankton Res. 20: 1567-1579.

Smith, V.H. 1983. Low nitrogen to phosphorus favors dominance by bluegreen algae in lake phytoplankton. Science (Washington, D.C.), 221: 669-671.

Sommer, U., Gliwicz, Z.M., Lampert, W., and Duncan, A. 1986. The PEG-model of seasonal succession of planktonic events in fresh waters. Arch. Hydrobiol. 106: 433-471.

Speziale, B.J., Schreiner, S.P., Giammatteo, P.A., and Schindler, J.E. 1984. Comparison of $N, N$-dimethylformamide, dimethyl sulfoxide, 
and acetone for extraction of phytoplankton chlorophyll. Can. J. Fish. Aquat. Sci. 41: 1519-1522.

Sprung, M., and Rose, U. 1988. Influence of food size and food quantity on the feeding of the mussel Dreissena polymorpha. Oecologia, 77: 526-532.

Stoermer, E.F., and Theriot, E. 1985. Phytoplankton distribution in Saginaw Bay. J. Gt. Lakes Res. 11: 132-142.

Ten Winkel, E.H., and Davids, C. 1982. Food selection by Dreissena polymorpha Pallas (Mollusca: Bivalvia). Freshwater Biol. 12: 553-558.

Tessier, A.J., and Lauff, G.H. 1992. The Gull Lake story. Michigan Riparian, Inc., P.O. Box 249, Three Rivers, MI 49093, U.S.A. pp. $12-14$.

Vanderploeg, H.A. 1994. Zooplankton particle selection and feeding mechanisms. In The biology of particles in aquatic systems. Edited by R.S. Wotton. Lewis Publishers, Boca Raton, Fla. pp. 205-234.

Vanderploeg, H.A., Scavia, D., and Liebig, J.R. 1984. Feeding rate of Diaptomus sicilis and its relation to selectivity and effective food concentration in algal mixtures and in Lake Michigan. J. Plankton Res. 6: 919-941.

Vanderploeg, H.A., Liebig, J.R., and Nalepa, T.F. 1995. From picoplankton to microplankton: temperature-driven filtration by the unionid bivalve Lampsilis radiata siliquoidea in Lake St. Clair. Can. J. Fish. Aquat. Sci. 52: 63-74.

Vanderploeg, H.A., Liebig, J.R., and Gluck, A.A. 1996. Evaluation of different phytoplankton for supporting the development of zebra mussel larvae (Dreissena polymorpha): the importance of size and polyunsaturated fatty acid content. J. Gt. Lakes Res. 22: $36-45$.

Walz, N. 1978. The energy balance of the freshwater mussel Dreissena polymorpha Pallas in laboratory experiments and in Lake Constance. I. Pattern of activity, feeding and assimilation efficiency. Arch. Hydrobiol. Suppl. 55: 83-105.

Ward, J.E., Levington, J.S., Shumway, S.E., and Cucci, T. 1998. Particle sorting in bivalves: in vivo determination of the pallatial organs of selection. Mar. Biol. 131: 283-292. 